\title{
THE VARIETIES OF NORMATIVITY: AN ESSAY ON SOCIAL ONTOLOGY
}

\author{
Leo Zaibert and Barry Smith*
}

For much of the first fifty years of its existence, analytic philosophy shunned discussions of normativity and ethics. Ethical statements were considered as pseudo-propositions, or as expressions of pro- or con-attitudes of minor theoretical significance. ${ }^{1}$ Nowadays, in contrast, there are prominent analytic philosophers who pay close attention to normative problems and important books written by such philosophers on topics in law and social justice and on social and institutional ontology. Here we focus our attention on the work of Searle, at the same time drawing out an important connection between Searle's work and that of two other seminal figures in this development: H.L.A. Hart and John Rawls.

Hart was, within the context of recent analytic philosophy, the most important philosopher of law and Rawls the most important political philosopher. Still a child of the 20th century, as we shall see, Searle tends to assume that there is but one type of normativity within the realm of social institutions. Like Hart and Rawls, he thereby neglects features which are of crucial significance for an adequate understanding of social reality. ${ }^{2}$ Our main goals are twofold. On the one hand we wish to expose how this neglect constitutes a shortcoming of Searle's ontology of social reality. ${ }^{3}$ On the other hand, our attention to the ways in which this neglect plays out in the normative philosophy of other luminaries of 20th century analytic philosophy should help us to identify an entrenched trend, and also thereby contribute to its reversal.

\footnotetext{
* The authors thank the Alexander von Humboldt Foundation, Ingvar Johansson, Kevin Mulligan, Mariam Thalos, and Raimo Tuomela. This article draws on discussions in Zaibert 2005 and in Smith 2003. ${ }^{1}$ See, e.g., Hare 1963, Ayer 1952, Wittgenstein 1965.

${ }^{2}$ Among the most important contributions to the field of social ontology we find Bratman (1999), Gilbert (1989), Searle (1995, 2001), Tuomela (1995, 2002).

${ }^{3}$ We shall follow Searle's lead in accepting a distinction between social and institutional reality. According to Searle institutional facts are a subset of social facts, characterized by the fact that they involve the transmission, cessation, or creation of power, whereas social facts do not directly relate to power. See Searle 1995: 38, 79ff. Searle rejects, however, the idea of a sharp distinction between these two classes (1995: 88ff.).
}

157

S.L. Tsohatzidis, (ed.), Intentional Acts and Institutional Facts, 157-173.

(C) 2007 Springer. 


\section{HART AND SOFT POSITIVISM}

We first set the stage for our more detailed treatment of Searle's views on normativity with a discussion of Hart and Rawls. The work of Hart, especially, forms part of a famous debate between natural law theorists and legal positivists, a debate which reveals that the question of the ontological status of laws has historically been linked to normative issues of moral philosophy. Natural law theorists affirm that immoral law is not law; that is, they believe that the ontological status of laws is determined by their relation to morality, in accordance with the famous motto: "Non videtur esse lex quae justa non fuerit". Legal positivists, on the other hand, insist that law is law independently of whether or not it is moral. According to the classical legal positivism of John Austin, for example, the issue of the legal status of law is an entirely empirical affair, to be established primarily through the determination of pedigree and enforceability. Was the entity or institution created and maintained in existence in accordance with the right sorts of rules? Is the entity such that the state can coerce people into complying with it?

According to Austin, we are to understand the nature of a legal system by starting out from the case of someone forcing someone else at gunpoint to hand over his wallet. The normativity of the law differs from the normativity of the highwayman only in this: that the law normally functions on the basis of threats alone; only in extreme circumstances it is necessary to bring guns into play.

In The Concept of Law (first published in 1961, references below are to the second edition, Hart 1994), Hart deploys a sustained attack on traditional legal positivism. His criticism of Austin is both elegant and persuasive. Hart himself still defends a positivistic conception of the ontological status of the law, but he rejects traditional positivism, above all because of its superficial treatment of rules. The rules the gunman imposes upon his victim - "Hand over your wallet", "Don't do anything stupid" - are all of the same type: they demand certain sorts of conduct. The law, however, operates on the basis of two types of rules, which Hart calls primary and secondary. Primary rules are duty-imposing; they demand conduct in just the way in which the gunman's actions do. Secondary rules are power-conferring; they make certain sorts of situations possible - they are rules about rules. A rule that states that a judge is entitled to decide how to interpret a primary rule is a secondary rule; it gives the judge the power to settle disputes by establishing what the correct interpretation of a law is.

It is possible, perhaps, to imagine an entire society in which there existed only primary rules. But such a society would be profoundly inept when it comes to resolving controversies about the laws themselves or about their interpretation. A situation, on the other hand, in which secondary rules would arise in relation to highwaymen robbing stagecoaches belongs, at best, to the world of Monty Python.

With only one kind of rule in its conceptual armoury, Hart argues, traditional positivism is unable to distinguish between two crucially distinct phenomena: (1) being de facto obliged and (2) having a genuinely normative obligation. If a gunman puts a gun to your head, you might indeed be, as a matter of empirical fact, obliged to hand over the money. For you to have a normative obligation, in 
contrast, it is necessary that you accept not only the empirical fact of your being obliged but also the rightness of the system which makes this so (even if you do not accept specific rules in this system). You accept that to do this or that is your duty; that it is the right thing to do. This notion finds no purchase in the realm of actions performed in response to gunmen's threats.

Hart refers to this dimension of acceptance as the "internal aspect" of obligations, to which he opposes an "external aspect"- the only one that traditional positivism is capable of explaining. He asks us to imagine someone describing the functioning of a street light in a busy intersection in the following way: when the street light becomes red in the direction of the cars, the likelihood that cars will stop, and that pedestrians will cross the street is very high; when the street light becomes green in the direction of the cars, the likelihood that cars will move forward and pedestrians will stay put increases. Obviously, Hart points out, such a description fails to mention a fundamental element of what is really going on. The red light is not merely a sign that allows us to predict that drivers and pedestrians will behave in this or that way; rather it is a reason which gives rise to this or that behavior. The red light indicates not simply that I stop, but that I ought to stop. This notion of a reason is not available to traditional legal positivism.

Since Hart is himself a positivist, it might look as if by introducing normative elements into his determination of the ontological status of laws he concedes too much to natural law theory. After all, for Hart as for natural law theorists, whether a given entity is or is not law depends on normative factors. He insists, however, that he has carved out an intermediate theoretical space between natural law and traditional positivism, which he calls "soft positivism" (Hart 1994: 250ff.).

Hart's strategy — though he does not himself admit it — is to distinguish between two types of normativity. On the one hand is the robust normativity of the natural law theorist, illustrated for example by the Ten Commandments. On the other hand is Hart's own brand of normativity - what we might call soft normativity which is what is necessary, in his view, for the existence of laws. Soft normativity is the sort of normativity that flows logically from the very nature of secondary rules. Secondary rules create institutions, and these institutions in turn create the very possibility of certain sorts of acts. Hart himself appeals to the example of games in order to illustrate this point (Hart 1994: 56ff., 141ff.). A group of people can play football without requiring the presence of a referee of any sort. But when a referee is present and disputes arise, then the referee will have the last word in resolving such disputes. His appointment is however possible only insofar as the players accept the secondary rules that make the institution of refereeing possible. That the referee has the last word is part of the content of the corresponding secondary rule, and it is this same rule which gives rise to the normative component in the referee's decisions. When a referee declares "penalty kick", for example, he is not merely providing an indication of what is likely to happen next (any more than a traffic light is providing an indication of likely traffic flows). Rather, his declaration is the very reason which explains what happens next, because it explains what ought to be done. 
But there is a problem with Hart's approach. The sense of 'ought' as expressing soft normativity, the sense of ought that is involved in rules of games like chess or football, is radically different from the sense of 'ought' that is involved, for example, when someone says that we ought to treat other human beings with respect, or that we ought not to gratuitously harm them. We believe that any ontology of legal institutions that does not do justice to the distinction between these types of normativity is doomed to fail.

\section{RAWLS AND RULE-UTILITARIANISM}

In 1955, at the beginning of his career, Rawls published an important article called "Two Concepts of Rules" (Rawls 1955; references below are to the reprint in Rawls 1999b), a work which was unfortunately overshadowed by his later A Theory of Justice (Rawls 1999a) but which has nonetheless exerted some considerable influence along the way. It has been translated into numerous languages and it is a mainstay in anthologies dealing with moral philosophy. It consists of an attempt to defend utilitarianism against certain traditional objections relating to the alleged incapacity of utilitarians to deal with the institutions of promise and of punishment, and to the widespread supposition that utilitarians must perforce allow on felicific grounds the occasional breaking of promises and the punishing of innocents.

Rawls's defense of utilitarianism, which has become a commonplace in many philosophical circles, goes roughly as follows: utilitarianism should not be seen as a theory that seeks to maximize general welfare in every instance. Rather, it is a theory that seeks to devise general rules of behavior of a sort that would tend to maximize welfare. The idea is that, once the rules have been established, then they must be followed, even if violating rules on this or that occasion yielded a net increase in general welfare. It is then unlikely that human beings would ever endorse on felicific grounds rules that would authorize the breaking of promises or the punishment of innocents.

In this way Rawls draws the nowadays familiar distinction between act- and rule-utilitarianism, and this constitutes the first half of his article. It is however the somewhat neglected second half which is important for our purposes. Indeed, the distinction which occupies him in the first half Rawls himself considers to be rather obvious (Rawls 1999b: 33). What he considers not obvious is the existence of a certain ambiguity regarding the notion of a rule, as between what he calls summary rules and practice rules.

A summary rule is simply a guide for action, formulated on the basis of experience. For example, if upon encountering caustic persons in the past one has established that the best course of action has been to keep a low profile, one might decide on encountering a caustic person now that it is best to do the same. Summary rules are inductive. The decisions they are based upon are logically prior to the rules themselves.

Rawls's practice rules, in contrast, are not inductive; they are not the result of such recollection of past events, and they are logically prior to the cases in which 
they are applied. An example of a practice rule would be the rules involved in games like baseball. Here the rules precede the game. What counts as a 'run' in baseball is not the result of looking back at what things have counted as 'runs' in past baseball games and then concluding: "well, this must also be a "run". Practice rules, rather, give rise to the very possibility that the cases in which they are applied can indeed occur. Thus they are not mere generalizations from past behavior. Practice rules define the very behavior which they at the same time permit. In chess, bishops move diagonally; the issue as to whether or not to move a bishop diagonally is not a genuine dilemma within the context of playing chess. If someone were to insist on moving his bishop non-diagonally, then he would eo ipso no longer be playing chess.

According to Rawls the rules of rule-utilitarianism are precisely practice rules. They are rules which define the very institutions they regulate. The normativity of rule utilitarianism, as Rawls conceives it, is the logical normativity of the system of propositions which describe institutions that rule-utilitarianism itself creates, such as promising and punishment. The State, for example, does not really have the option of whether or not to punish an innocent person, for punishing the innocent is logically forbidden by the very practice rule which sets up the institution of punishment itself (Zaibert 2003). Deciding to punish an innocent person is analogous to deciding to move a bishop non-diagonally in chess. As Rawls would have it: "To engage in a practice, to perform those actions specified by a practice, means to follow the appropriate rules" (Rawls 1999b: 37).

On Rawls's interpretation, then, the main difference between act- and ruleutilitarianism is not merely related to the issue of where to apply the welfaremaximizing measure (namely, to rules concerned with act-types rather than with act-tokens). Rather, rule-utilitarianism differs from act-utilitarianism in that it is a logical theory. In defending himself against charges that his view might be too conservative (insofar as he may be taken to blindly endorse the status quo of existing social institutions), Rawls states: "The point I have been making is rather a logical point", and then he continues: "where a form of action is specified by a practice there is no justification possible of the particular action of a particular person save by reference to the practice" (Rawls 1999b: 42). Utilitarianism in the hands of Bentham and Mill is a moral theory concerned with the same substantial normative issues as are addressed by natural law theorists; Rawls transforms it into a logical doctrine.

Whereas in "Two Concepts of Rules" Rawls seeks to defend utilitarianism, in $A$ Theory of Justice and other later works he seeks to develop a neo-Kantian theory of the justice of social institutions that is opposed to utilitarianism. Yet there is nonetheless a certain connecting thread between the two works, which is the importance Rawls gives to the logical structure of institutions. The emphasis on procedural and formal justice in A Theory of Justice (Rawls 1999a: 74ff. and passim) can be seen as a reflection of the logicist leanings found in his early defense of utilitarianism. Focusing on Rawls' concern with the logic of institutions allows us to see the two works within a single context, and it allows us also to see the challenge which Rawls faces: in transforming normativity as traditionally 
conceived into a matter of the logical consequences of rules of a certain type, rules which we adopt when we choose to engage in certain practices, Rawls (like Hart) makes questions like: "Why should we keep promises?" or "Why should we endorse a social order based on these or those principles?" of a piece with the question "Why should we play the game of chess rather than some other, slightly different game?" Let us turn now to Searle, and see how he seems to face a similar fate.

\section{SEARLE AND OBLIGATIONS}

In one of his earliest articles, "How to Derive 'Ought' From 'Is"” (Searle 1964), Searle claims that he found a way of showing that from purely descriptive premises we can derive normative conclusions. In other words, that he has shown how to bridge the gap between "is" and "ought", between matters of fact and judgments of value.

The best place to begin our discussion is Searle's analysis in Speech Acts of what he calls "The Naturalistic Fallacy Fallacy": "the fallacy of supposing that it is logically impossible for any set of statements of the kind usually called descriptive to entail a statement of the kind usually called evaluative" (Searle 1969: 132). The view that Searle wishes to defend is, in his own words, that:

the view that descriptive statements cannot entail evaluative statements, though relevant to ethics, is not a specifically ethical theory; it is a general theory about the illocutionary force of utterances of which ethical utterances are only a special case.

How can I become obliged by merely uttering certain words, say, "I promise to mow your lawn"? Searle's gambit, in embryo, is as follows. He wants us to see the traditional problem of the naturalistic fallacy as a particular case of a putatively more general problem in speech act theory. It is then this latter problem, of the normativity associated with speech acts, which Searle sets out to solvenot, as many authors have too quickly assumed, the traditional problem of moral normativity.

Searle himself is emphatic about the fact that whatever relevance his views might have regarding moral normativity would be a mere side effect of his concern with a logical problem about the illocutionary force of certain utterances. As a propaedeutic warning, he tells us that we must avoid "lapsing into talk about ethics or morals. We are concerned with 'ought' not 'morally ought"' (1969: 176). And again: "Let us remind ourselves at the outset that 'ought' is a humble English auxiliary, 'is' an English copula; and the question whether 'ought' can be derived from 'is' is as humble as the words themselves" (1969: 176). The humble sense of 'ought' with which Searle is concerned is the same sense as that in which, when playing chess, you ought to move your bishop diagonally. We note in passing that this sense of 'ought', interesting as it might be, is at best of indirect significance for moral philosophy.

Searle's treatment of the humble sense of 'ought' is reminiscent of another treatment of these matters in the writings of A.N. Prior, who noted that, from 
the premise that "Tea drinking is common in England", one could validly infer that "either tea drinking is common in England or all New Zealanders ought to be shot" (Prior 1949). ${ }^{4}$ Of course, this inference constitutes no contribution whatsoever to the solution of the metaethical problem regarding the nature of moral propositions.

To be sure, Searle's derivation of an 'ought' from an 'is' is not as vacuous as Prior's reductio. But it is similarly irrelevant to ethics. For it merely tells us something about the meaning of the word 'promise'. Promising means undertaking an obligation, and undertaking an obligation means that one ought to do whatever one has obliged oneself to do. The problem is that this sense of obligation falls short of capturing the sort of obligation that involves moral normativity. As Searle admits, "whether the entire institution of promising is good or evil, and whether the obligations undertaken in promising are overridden by other outside considerations are questions which are external to the institution itself" (1969: 189). Such external considerations are very often precisely of a moral nature.

There is something odd, then, about Searle's attempt to examine what he describes as the general problem of the naturalistic fallacy, for the classical interest of philosophers in this fallacy has been focused precisely on its properly ethical dimension. So it was for Hume (1888), for Moore (1959), and for Popper (1966). These authors leave no doubt that they are dealing with an ethical problem.

The problem with Searle's treatment of the naturalistic fallacy is brought out nicely by D.D. Raphael in the context of writing on the justification about political obligations. Why does the citizen have a duty to obey the laws about the State? Raphael points out that there is an answer to this question which is "simple and obvious": "It follows logically that if the State is authoritative, i.e., has the right to issue orders to its citizens and the right to receive obedience from them, the citizens are obliged to obey those orders" (Raphael 1990: 175, emphasis added). Raphael rubs home the downright platitudinous character of this sort of answer: "the citizen is legally obliged to obey the law because the law is that which imposes legal obligations" (1990: 175). And then he compares this sort of answer with the passage in which Hamlet is asked by Polonius, "What do you read my lord?" and Hamlet replies, "Words, words, words". Though both answers are "formally correct", as Raphael puts it, they tell us "virtually nothing" (1990: 175). Something similar happens with Searle's derivation of 'ought' from 'is'. The very meaning of promising is that one ought to do what one has promised to do. But this sense of 'ought' is indeed humble, and it is dramatically different from the sense of 'ought' that has preoccupied moral philosophers throughout the ages.

In spite of his reminding us of the humble nature of the problem he seeks to solve, toward the end of his derivation of 'ought' from 'is', Searle asks: "what

\footnotetext{
${ }^{4}$ See also David Brink's discussion of naturalism in Brink 1989: 150ff.
} 
bearing does all this have on moral philosophy?" His answer deserves to be quoted in full, with emphasis added:

At least this much: It is often claimed that no ethical statement can ever follow from a set of statements of fact. The reason for this, it is alleged, is that ethical statements are a sub-class of evaluative statements, and no evaluative statements can ever follow from a set of statements of fact. The naturalistic fallacy as applied to ethics is just a special case of the general naturalistic fallacy. I have argued that the general claim that one cannot derive evaluative from descriptive statements is false. I have not argued, or even considered, that specifically ethical or moral statements cannot be derived from statements of fact. (Searle 1969: 187)

Clever as Searle's manoeuvre is, it nonetheless misrepresents the case that has traditionally been made by those who believe that there is an is/ought gap. Classical moral philosophers have not subsumed the ethical problem under the general speech act problem in order then to show that, since there is a gap concerning that general problem, the gap must extend to the particular ethical version of the problem. It has been enough to point out that there is no way to bridge the gap in the particular case of morality. Searle is rather alone in his interest in the general naturalistic fallacy.

In his famous article Searle states that he is going to show that the venerable view to the effect that 'ought' cannot be derived from 'is' is flawed by presenting a counterexample to this view. He then says:

It is not of course to be supposed that a single counter-example can refute a philosophical thesis, but in the present instance if we can present a plausible counter-example and can in addition give some account or explanation of how and why it is a counter-example, and if we can further offer a theory to back up our counter-example - a theory which will generate an indefinite number of counter-examples - we may at least cast considerable light on the original thesis. (Searle 1964: 43)

The needed theory has been long in the making. Speech Acts, in which "How to Derive 'Ought' From 'Is" was reprinted with minor modifications, was indeed the first step; but it is only with the publication of his two most recent major works-The Construction of Social Reality (Searle 1995) and Rationality in Action (Searle 2001) — that we have Searle's views on the ways in which speech acts contribute to the construction of social institutions. Indeed, Searle's philosophy has gained in depth and in comprehensiveness with these recent works - but then for this very reason the neglect of morality within his total system is all the more striking.

The world Searle investigates in these two books includes "the world of Supreme Court decisions and of the collapse of communism" (Searle 1995: 120); it includes marriages, money, government, and property rights, and discussions about altruism and egoism. And Searle expressly claims to be interested in the "basic ontology of social institutions" - of all social institutions. Yet still he avoids tackling head on the problem of the normativity of social institutions. In these recent works he has emphasized above all the importance of 
promising. Promises, he tells us, are present in "all" or "virtually all" speech acts. ${ }^{5}$ Marriages, money, property rights, and contracts all contain promises. And promises create obligations. But how?

Searle's answer is elegant and complex. As in Hart and Rawls, it revolves around a distinction between two types of rules, which in terms coined by Searle already in Speech Acts, are called 'regulative' and 'constitutive'. Regulative rules regulate forms of behavior that exist independently and antecedently (Searle 1969: 33). Constitutive rules - like Hart's secondary rules and Rawls's practice rules - create or define new forms of behaviour (Searle 1969: 34ff.). Thus when someone violates a constitutive rule, he eo ipso places himself outside of the institution to which the form of behavior defined by the rule belongs. Violating a regulative rule, in contrast, may give the violator a reputation for bad manners or reckless driving, but does not ipso facto place him outside of any institutions.

Rules of etiquette are regulative. It is perfectly intelligible to say that someone acted in ways that satisfy such rules even if that someone is unaware of the fact that he was satisfying such rules. Contrast this case with a community in which a group of 22 people gather together and move about while kicking a ball in more or less the same way as would a group of people playing football; they would not really be playing football unless a set of rules defining football was already in existence, and unless they knew about these rules. The latter constitute the very possibility of the activity of playing football.

\section{ON SOFT NORMATIVITY}

We wish to refer back to the notion of 'soft' normativity we introduced above, and suggest that it is an accurate corollary to Searle's (and Hart's and Rawls's) views that they characterize the normativity of social institutions as soft - of a piece with the normativity we find in games. ${ }^{6}$ The constitutive-rules-based 'oughts' of games are, however, defeasible to a very high degree. Certainly when playing baseball one ought to go to first base after four bad pitches are thrown, but no one ought (in any interesting sense) to play baseball in the first place: any baseball player can walk off the field, can abandon the game, any time he wishes - though of course if a professional baseball player were to do this, he would probably lose his job.

This last remark reminds us that there are other types of oughts in games, in addition to those based in constitutive rules. For example: one ought to remain in the baseball field even after humiliating oneself by missing an easy catch. Players in a game of basketball can 'foul' their opponents several times in order

\footnotetext{
${ }^{5}$ Searle 2001: 181. In the Spanish version of Rationality in Action, which was published earlier than the English version, and which is virtually identical to the latter, it is stated that "all" (not merely "virtually all") speech acts contain an element of promising.

${ }^{6}$ See, for example, the section entitled "Games and Institutional Reality" in Searle 1995: 66-71.
} 
to prevent them from scoring, but they ought not to stab or shoot their opponents. One might try to explain the latter sorts of normativity by appealing to the fact that, for example, by embarking on a game of baseball one has in a sense promised not to leave the playing field after making silly mistakes, or that all human beings have in a sense promised not to kill in general and that this promise covers also one's behavior when playing basketball. This strategy, however, robs terms like 'promise' and 'contract' of their customary meanings. Moreover, at least some of the mentioned obligations seem not to be obligations of the sort which one could acquire by means of promises or contracts.

Legal and sociopolitical institutions, similarly, give rise to obligations not only of the constitutive-rule-based sort but also of other sorts. According to Hart, for example, Nazi laws are genuine laws in the constitutive-rule-based sense - but they are at the same time laws that one should not follow. Famously, Hart charged that Gustav Radbruch's abandonment of positivism in the postNazi era was the result of his "half-digested" understanding of "the spiritual message of liberalism" (Hart 1997: 31), whereby Radbruch had failed to see that even the staunchest positivists share the "conviction that if laws reached a certain degree of iniquity then there would be a plain moral obligation to resist them and withhold obedience" (Hart 1997: 30). Presumably, Hart would agree that this "plain moral obligation" is not a game-related obligation. Significantly however he does not discuss what type of obligation it might in fact be, and this is the sort of discussion that Searle avoids as well.

To see that something is wrong with the identification of all normativity with the normativity of games, we can appeal to Wittgenstein's remarks on the nature of games in the context of his treatment of the notion of family resemblance in the Philosophical Investigations (Wittgenstein 1953: § 66ff.). According to Wittgenstein, no definition formulated in terms of necessary and sufficient conditions can apply to all games. In light of Searle's views on what we have called soft-normativity, however, it is tempting to suggest that being created by a set of constitutive rules would amount, precisely, to the sought-for definition. Whenever you are in the presence of an entity which exists in virtue of constitutive rules, you are eo ipso in the presence of a game, and vice versa.

This resolution of Wittgenstein's puzzle comes at a price, however-for it forces an over-large scope upon the notion of game, which now turns out to include sociopolitical institutions like promising, punishment, marriage, and government. Note that if Searle and our authors are correct, then this would in no way count against it. For whenever Searle, Hart, and Rawls wish to explain the normativity of such institutions they do indeed invariably end up talking about the way in which swinging at the third strike entails that you ought to leave the baseball field. This move, if we are right, is not a matter of happenstance. Rather, it reveals that Searle and our other authors have maneuvered themselves into a position where they do not have the tools to draw the distinction between games and sociopolitical institutions. 
Part of the compelling force of the "why should I play this game anyway?" objection to the thesis that all normativity is soft normativity turns on the conventional character of games. For even if there existed something like a game of life (Ralls 1966), the skeptic could still ask a reformulated question: "Why should we not alter its rules?" Constitutive rules, after all, are not merely to a high degree defeasible, they are also easy to change: at some point in their history virtually all games had rules different from those they have today.

Hospitals are, by definition, places where physicians and nurses ought to care for patients. If there were a hospital in which nurses and physicians systematically harmed their patients, then we would not be content simply to claim that this institution is, by definition, no longer a hospital and leave it at that. Obviously, we would claim that the physicians and nurses ought to care for their patients, and that this obligation is not merely the result of the constitutive rules governing hospitals and medical professions.

Other sorts of normative claims: that murder is wrong, or that it is appropriate for wrongdoers to apologize, that purely accidental (nonnegligent) wrongdoing is not blameworthy, etc., are not only not easily defeated, they are also - and even more conspicuously - not easily changed. Whereas the number of fouls a basketball player can 'legally' make in the course of a game can at any time be changed, the prohibition against stabbing his opponents is not likely to change at all.

\section{ON ROBUST NORMATIVITY}

In spite of the fact that Hart cares about legal institutions, that Rawls cares about political institutions, and that Searle cares about social institutions, they, and the legions who have followed in their footsteps, have all avoided addressing the challenge encapsulated in Raphael's charge of triviality - the challenge that their respective logical analyses tell us "virtually nothing" about the normativity that is interwoven in the fabric of institutions of the various non-gamerelated types referred to in the foregoing. For aside from the sorts of normative demands to which secondary rules, practice rules, and constitutive rules give rise, there exist in law, politics and society other types of demands which are similarly non-conventional. Each of us believes that he has an obligation to respect other human beings; each of us believes that he has an obligation to apologize to those we have wronged. These beliefs do not depend for their existence on any promises we have made, and neither do the associated obligations. Each of us believes, similarly, that intentional wrongdoing ought to be blamed more severely than unintentional wrongdoing; each of us believes that wrongdoers ought to be blamed. These views, again, are clearly normative, and they do not depend for their existence on any promises or contracts.

We believe (with Searle) that a minimum dose of realism is necessary for any sane philosophy (Searle 1955: xiii and Chap. 7 passim). Moreover (also with Searle) we understand realism as an ontological thesis: "realism . . . is not a theory 
of truth, it is not a theory of knowledge, and it is not a theory of language", and Searle himself has recently admitted that "if one insists on a pigeonhole, one could say that realism is an ontological theory: it says that there exists a reality totally independent of our representations" (Searle 1995: 155). Yet Searle avoids the discussion of realism as pertains to the dimension of moral normativity. Indeed at crucial junctures Searle shuns ontology entirely. Thus, in the introduction to Intentionality, Searle praises the methodological advantages of approaching the analysis of mental phenomena from the perspective of intentionality in the following terms: "one advantage to this approach, by no means a minor one, is that it enables us to distinguish clearly between the logical properties of Intentional states and their ontological status; indeed, on this account, the question concerning the logical nature of Intentionality is not an ontological problem at all" (Searle 1983: 14). Searle believes that a logical approach to intentional phenomena can allow him to repeat the success of his logical analyses of obligation in "How to Derive 'Ought' From 'Is"'. In Rationality in Action, still more recently, Searle has suggested that we can enjoy some of these same benefits by providing a logical account of notions such as self, freedom, and responsibility; that is, that we can talk about these notions without having to deal with the embarrassing ontological questions that had affected their treatment in earlier times.

In tandem with the shunning of realism as it pertains to ethics, of course, goes the shunning of precisely those types of normativity which are not soft. We can morally criticize Nazi institutions; we can accept that promises do not obligate if what is promised is itself immoral, we can expect - and sometimes acceptapologies when we are wronged. But to tackle theoretically these genuinely moral dimensions of social institutions we need to go beyond merely tracing the logical paths connecting speech acts, institutions, and consequent obligations.

To see what more is needed, let us pay closer attention to the normativity that is associated with our intentional states. This is, we suggest, more fundamental than the normativity associated with speech acts. Paradoxically, perhaps, we find some support for this thesis in Searle's own philosophy, above all at the outset of Intentionality, where he writes:

A basic assumption behind my approach to problems of language is that the philosophy of language is a branch of the philosophy of mind. The capacity of speech acts to represent objects and states of affairs in the world is an extension of the more biologically fundamental capacities of the mind (or brain) to relate the organism to the world by way of such mental states as belief and desire, and especially through action and perception. (Searle 1983: vii)

We fully agree with Searle's assumption regarding the priority, biological and otherwise, of intentional states over speech acts, though we wish he had done more to exploit this insight in his recent work on social reality. We say this not because we deny the general value of speech act theory. Our claim is, precisely, that its value should not be overestimated, and that in particular the concern 
with practice, secondary or constitutive rules which we find in Hart, Rawls, and Searle has already yielded all the fruits that it is worth collecting. Constitutive rules do give rise to claims which exhibit some sort of normative force, but they are not nearly the end of the story of normativity.

A no less vital chapter in this story deals with a different sort of normative force - that which derives from intentional states. What happens if we focus not on speech acts in giving an account of legal and sociopolitical institutions, but rather on the intentional states which underlie them? Speech acts are in their entirety contingent, first in the sense that one can choose to perform them or not, and secondly in the sense that they need not have existed at all. It is indeed hard to imagine a society in which something resembling promising did not exist, but given Searle's analysis of speech acts as products of constitutive rules such a society is not impossible. Some intentional states are not contingent in either of these two senses.

By Searle's own admission, the intentional state of intending is crucially important for promising: if you promise to $\mathrm{X}$ then you must intend to $\mathrm{X}$. But where the skeptic can raise the concern as to why he should play the "promising game", there is no parallel concern in relation to the phenomenon of intending. This is because what happens when one intends is not the result of applying human conventions. And while it is hard to imagine a society which did not develop a practice more or less identical to promising as we know it, it is downright impossible to think of human beings who do not intend.

\section{THE NORMATIVITY OF INTENTIONS}

The structure of intending is rather complicated, and it is the subject of a very extensive debate. Virtually all participants to this debate, however, agree that intending is subject to more stringent rational considerations than are other intentional states. We could have contradictory desires without thereby being irrational, but for one who has contradictory intentions, i.e., one who intends to have a meal and not to have a meal simultaneously, a charge of irrationality will almost always succeed.

Intentions are connected to actions in ways in which mere desires are not. You can only intend to do things that you believe are up to you, and when you intend to do $\mathrm{X}$, then if your intention is to be fulfilled $\mathrm{X}$ must come about "in the right way", i.e., in the way the intending agent foresees that X should come about. These two features of intentions not only distinguish them from related phenomena like desires or wishes, but also explain why intending to do $\mathrm{X}$ commits us in certain ways. If you form an intention today to visit friends tomorrow, forming that intention somehow settles your deliberative process; you are now committed to visit your friends tomorrow. This does not mean that you cannot possibly change your mind: the commitments that arise from intentions are defeasible, just like those that arise from promising. But there is nonetheless a stark contrast between the way commitments arise from intentions and the way 
they arise out of speech acts. Forming intentions is itself optional, but once they are formed, the commitments which follow from them do not arise in virtue of constitutive rules imposed, as it were, from without; rather, they arise solely in virtue of the intrinsic nature of the intentions themselves.

Imagine that you communicate to your students your intention to tidy up your office. Month after month, indeed semester after semester, students visit you and see that you have done nothing of the sort: your office is ever messier. Regularly they ask: "What about your intention to tidy up your office?", to which you reply: "It is still there". Nothing has prevented you from carrying out your intention; you simply have not done so. After some time your students will be justified in believing that either you do not have the intention to clean your office at all (that you have been lying, or confused as to what it is to have an intention), or that, if you do have the intention, then you are somehow irrational.

If, in contrast, you had merely wished or desired to tidy up your office, then your inaction would be evidence neither of irrationality nor of dissimulation or confusion. This is not to say that there are no constraints on what we can desire. Your desire that a fairy godmother should materialize and tidy up your office would properly be counted as a sign of irrationality, just as would the corresponding cognitive state of believing that a fairy godmother is on her way to do the job. Such constraints are, however, more stringent in the case of intentions than in the case of other mental states.

What does this tight connection between intentions and rationality tell us about normativity? We note, first, that acting goes hand in hand with the possibility of blame. Acting intendedly means acting in such a way that one is committed to acting in precisely the way one acts. If, therefore, what one does intendedly is a bad thing, then one is clearly at least not less blameworthy for doing it than if one had done it unintendedly. This normative principle, namely that intended wrongdoing ought to be blamed more severely than unintended wrongdoing, is rooted in the intrinsic nature of the phenomenon of intending, and not related to conventional constitutive rules.

The same reasoning explains why doing bad things on the basis of a commitment to those bad things is evaluated differently from doing those same bad things in the absence of such commitment. Regardless of whatever general character traits one possesses, being committed to a bad thing makes one, ceteris paribus, no less blameworthy than if one does this bad thing without being so committed. This normative principle follows, again, from the intrinsic nature of intentions, and it is quite unlike those normative claims that follow from conventional constitutive rules.

In order to drill home this point it is profitable to take a look at Christine Korsgaard's Locke Lectures which open with a statement to the effect that "Human beings are condemned to choice and action". ${ }^{7}$ This statement is part of

\footnotetext{
${ }^{7}$ Korsgaard's lectures are available at: http://www.people.fas.harvard.edu/ korsgaar/\#Locke\%-20Lectures, from which all quotations here are taken.
} 
Korsgaard's ambitious project of showing how "we human beings constitute our own personal or practical identities - and at the same time our own agency - through action itself. We make ourselves the authors of our actions, by the way that we act". Clearly, when Korsgaard says "through action" she means "through intentional action". Indeed, she points out that

to call a movement a twitch, or a slip, is at once to deny that it is an action and to assign it to some part of you that is less than the whole: the twitch to your eyebrow, or the slip, more problematically, to your tongue. For a movement to be my action, for it to be expressive of myself in the way that an action must be, it must result from my entire nature working as an integrated whole.

Twitches are not actions because they do not express our selfhood in any meaningful way. Slips are more problematic precisely because slips of the tongue can in some cases be actions, though except in rare and contrived cases, unintended actions. It is however precisely intentions which constitute our selfhood; and it is intentions, too, which constitute the principal grounds for blameworthiness of our actions.

According to Korsgaard "there is no you prior to your choices and actions, because your identity is in a quite literal way constituted by your choices and actions". And then Korsgaard adds:

The identity of a person, of an agent, is not the same as the identity of the human animal on which the person normally supervenes. Human beings differ from the other animals in an important way. Because we are self-conscious, and choose our actions deliberately, we are each faced with the task of constructing a peculiar, individual kind of identitypersonal or practical identity - that the other animals lack. It is this sort of identity that makes sense of our practice of holding people responsible, and of the kinds of personal relationships that depend on that practice.

What distinguishes our identity from that of animals is, in other words, our capacity to act intentionally; our capacity to act intentionally is of course wholly dependent upon our more fundamental capacity to form intentions. And, ultimately, it is these capacities to form intentions and to carry them through which make sense, not only of the practice of "holding people responsible", but of other normative phenomena such as the apportioning of praise and blame.

The intrinsic nature of intentions gives rise in this way to important normative principles. As R. Jay Wallace puts it, the intentional actions, and ultimately the intentions, of morally responsible people "are thought to reflect specially on them as agents, opening them to a kind of moral appraisal that does more than record a causal connection between them and the consequences of their actions." (Wallace 1996: 52) In order for agents to be the subjects of judgments of praise and blame it is necessary that agents be autonomous beings, and the role played by intended action in the constitution of this autonomy is a rich and still untapped source of insight. 


\section{CONCLUSION}

The normative principle to the effect that to bring about an evil outcome intentionally is never less blameworthy than to bring it about unintentionally is in no sense analogous to the principle that in chess bishops move diagonally. For the rules of chess are open to deliberation. One could choose or invite others not to play chess; one could propose that chess be played differently; and thus one could affect the way in which the soft normativity of chess plays itself out in reality. One cannot, in contrast, refuse to accept or propose adjustments in the normativity of intending.

There is, then, normativity in intentional states themselves, before they give rise to speech acts. But this is still not the end of the story as concerns the manifold varieties of normativity. Thus we still cannot explain why murder is wrong. And we still do not yet have the means to do justice to those features of normativity turning on virtue, character traits, and like phenomena, which are the fare of neo-Aristotelian ethics. Our discussion of intentions is meant simply to establish that there are provinces in the kingdom of normativity that have nothing to do with conventional rules. Surely some of these provinces affect the structure of social ontology: it is rather hard to accept that all social reality is a matter of soft normativity, yet it is a view of this sort with which Searle's otherwise groundbreaking work on social ontology is still stuck.

\section{REFERENCES}

Ayer, A.J. (1952). Language, Truth and Logic. New York: Dover.

Bratman, M. (1999). Faces of Intention. Cambridge: Cambridge University Press.

Brink, D. (1989). Moral Realism and the Foundations of Ethics. Cambridge: Cambridge University Press.

Gilbert, M. (1989). On Social Facts. London: Routledge.

Hare, R.M. (1963). Freedom and Reason. Oxford: Oxford University Press.

Hart, H.L.A. (1994). The Concept of Law. Second Edition. Oxford: Oxford University Press.

Hart, H.L.A. (1997). Positivism and the separation of law and morals. In R. Dworkin (ed.), The Philosophy of Law. Oxford: Oxford University Press.

Hume, D. (1888). A Treatise Concerning Human Understanding. Ed. L.A. Selby-Bigge. Oxford: Clarendon Press.

Moore, G.E. (1959). Principia Ethica. Cambridge: Cambridge University Press.

Popper, K. (1966). The Open Society and its Enemies, Vol 1, rev. edn. Princeton, NJ: Princeton University Press.

Prior, A.N. (1949). Logic and the Basis of Ethics. Oxford: Oxford University Press.

Ralls, A. (1966). The game of life. Philosophical Quarterly, 62: 23-34.

Raphael, D.D. (1990). Problems of Political Philosophy. Second Edition. Atlantic Highlands, NJ:

Humanities Press.

Rawls, J. (1955). Two concepts of rules. The Philosophical Review, 64: 3-32.

Rawls, J. (1999a). A Theory of Justice. rev. edn. Cambridge, MA: Harvard University Press.

Rawls, J. (1999b). Collected Papers. Ed. S. Freeman. Cambridge, MA: Harvard University Press.

Searle, J.R. (1964). How to derive 'ought' from 'is'. The Philosophical Review, 73: 43-58.

Searle, J.R. (1969). Speech Acts. Cambridge: Cambridge University Press.

Searle, J.R. (1983). Intentionality. Cambridge: Cambridge University Press. 
Searle, J.R. (1995). The Construction of Social Reality. New York: Free Press.

Searle, J.R. (2001). Rationality in Action. Cambridge, MA: MIT Press.

Smith, B. (2003). The ontology of social reality. American Journal of Economics and Sociology, 62: 285-299.

Tuomela, R. (1995). The Importance of Us: A Philosophical Study of Basic Social Notions. Stanford, CA: Stanford University Press.

Tuomela, R. (2002). The Philosophy of Social Practices: A Collective Acceptance View. Cambridge: Cambridge University Press.

Wallace, R.J. (1996). Responsibility and the Moral Sentiments. Cambridge, MA: Harvard University Press.

Wittgenstein, L. (1953). Philosophical Investigations, transl. G.E.M. Anscombe. Oxford: Blackwell. Wittgenstein, L. (1965). A lecture on ethics. The Philosophical Review, 74: 3-12.

Zaibert, L. (2003). Punishment, justifications, and institutions. Studies in Law, Politics, and Society, 30: $51-83$.

Zaibert, L. (2005). Five Ways Patricia Can Kill Her Husband: A Theory of Intentionality and Blame. Chicago: Open Court. 
Ch08.qxd 23/5/07 2:23 PM Page 174
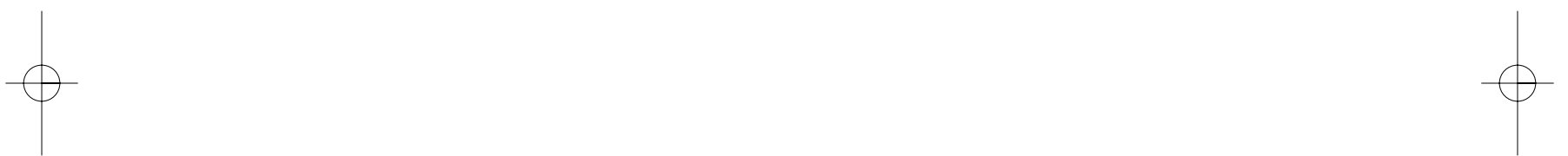